\title{
Funciones de vulnerabilidad calculadas para edificaciones en muros de hormigón reforzado
}

\section{Calculated seismic vulnerability functions for building in walls of reinforced concrete}

\author{
Esperanza Maldonado Rondón*1, Neyid Mauricio Jasbón Carvajal*, Gustavo Chio Cho* \\ * Universidad Industrial de Santander, Bucaramanga. COLOMBIA \\ Fecha de recepción: 09/ 12/ 2009 \\ Fecha de aceptación: 02/ 03/ 2010 \\ Resumen \\ PAG. 63 - 82
}

\begin{abstract}
En este documento se presenta una metodología que valora el nivel de daño que pueden alcanzar las edificaciones correspondientes al sistema estructural de muros de hormigón reforzado. El modelo estima un índice de vulnerabilidad calculado en función de las características de la estructura que más influyen en su comportamiento sísmico, y lo relaciona con un índice de daño, que a su vez depende de la acción del movimiento sísmico. El modelo estima diferentes grados de vulnerabilidad, y por consiguiente, define distintos niveles de daño ante una misma acción. La relación de la vulnerabilidad con el daño se materializa mediante una forma continua con las funciones de vulnerabilidad. El modelo se construyó sobre una muestra de edificaciones reales e hipotéticas las cuales representan las características más relevantes de las edificaciones de este tipo en el medio colombiano.
\end{abstract}

Palabras Clave: Vulnerabilidad sísmica, daño sísmico, muros de hormigón reforzado, funciones de vulnerabilidad sísmica

Abstract

This document contains a methodology to assess the level of damage that buildings with reinforced concrete wall structural system may reach. The model estimates a vulnerability rate calculated in function of structure characteristics that most influent a seismic behaviour, and relates this value to a damage rate, which, in turn, depends on the action of seismic movements. The model estimates different levels of vulnerability and, consequently, defines different damages produced the same action. The vulnerability / damage ratio is materialized to vulnerability function in a continuous manner. The model was constructed on a sample of real and hypothetical buildings representing the most relevant characteristics of this type of buildings in Colombia.

Keywords: Seismic vulnerability, seismic damage, reinforced concrete wall, seismic vulnerability functions

\section{Introducción}

En el desarrollo de los planes de ordenamiento territorial (POT) de las ciudades, se debe involucrar lo correspondiente a los escenarios de daño debido a amenazas naturales; y dentro de ello lo relacionado con los sismos es de gran importancia. Por consiguiente, es fundamental contar con estudios que permitan conocer el grado de daño que pueden alcanzar las edificaciones ante la acción de un sismo. De esta manera se puede planificar el desarrollo urbano, mitigar el riesgo y preparar a la comunidad para responder ante una amenaza sísmica.

\section{Introduction}

The development of territorial order plan in cities should consider circumstances of damaged due to natural threatens; and within that all the matters related with earthquakes are highly significant. Consequently, to have researches that show the kind of damages that buildings might have in case of earthquake is fundamental. This may possible to plan an urban development and to mitigate risks, preparing the community to react in front of a seismic threaten.

\footnotetext{
1 Autor de correspondencia / Corresponding author:

E-mail: emaldona@uis.edu.co
} 
Dentro de la estimación del daño se deben establecer las diferencias entre las distintas tipologías estructurales que existen en las edificaciones de una ciudad. En la actualidad el sistema de muros estructurales de hormigón es uno de los sistemas estructurales más usados en las ciudades colombianas; sin embargo, es uno de los menos considerados en este tipo de estudios. De aquí la importancia de investigar, y proponer modelos que estimen los niveles de daño que pueden alcanzar las edificaciones correspondientes a este sistema estructural, cuando ocurre un terremoto.

Independiente del sistema estructural los modelos para evaluar la vulnerabilidad; generalmente, cuantifican el daño a través de un índice de daño, el cual se determina bien sea por medio de las funciones de vulnerabilidad o por medio de las matrices de probabilidad de daño. Las principales metodologías usadas para la construcción de las funciones y las matrices, básicamente difieren en los datos, dado que pueden ser experimentales, analíticas o estar basadas en observaciones de campo o en la opinión de expertos. En el caso de la aplicación a ciudades colombianas, en las cuales no se cuenta con datos de daños sísmicos reales, ni con información experimental, se debe pensar en modelos aplicables a nuestros medios superando las deficiencias de la información. Por consiguiente, para superar este inconveniente se propone un modelo que considere las características de las edificaciones del entorno colombiano y que se base en opinión de expertos.

De esta forma, el presente trabajo ofrece un modelo de evaluación de la vulnerabilidad sísmica de edificaciones construidas con muros de hormigón reforzado basado en funciones de vulnerabilidad, las cuales involucran aspectos estructurales y constructivos del medio colombiano.

\section{Funciones de vulnerabilidad}

Una función de vulnerabilidad es una relación matemática que expresa de forma continua el daño que puede sufrir un tipo específico de estructura, cuando se somete a una solicitación sísmica de determinado nivel. Las funciones de vulnerabilidad se deducen por medio de una regresión estadística de los datos de daño observados o generados artificialmente. Una de sus principales variantes la constituyen las funciones de vulnerabilidad que relacionan un índice de vulnerabilidad con un índice de daño, condicionado por un parámetro que describe el movimiento del terreno; este parámetro puede ser la aceleración máxima $A_{a}$, o una de las escalas de intensidad sísmica, tales como MSK y MMI.
The differences between the structural classifications of building in the city should be defined within damage estimation. Nowadays the system of concrete structural walls is one of the most used in Colombian cities; nevertheless this is one of the less considered in this kind of researches. Thus the importance of investigation and suggesting models to estimate the level of damage that buildings with this structural system may have in case of earthquake.

Besides the structural system, the models that evaluate vulnerability usually use a damage rate which is determined either by vulnerability functions or damage probability matrix. The main methodologies used for defining functions and matrix; basically differ in records, which may be experimental, analytic or being based on field observations or in the opinion of experts. In the case of Colombian cities, where real seismic information is not available, nor experimental information, the methods to be used should be thought in regard to our models overcoming deficiencies of information. Consequently, the suggestion to overcome this inconvenient is to using a model based on the opinion of experts and on the Colombian environmental building features.

Thus, the present paper offers a model to assess the seismic vulnerability of buildings that have reinforced concrete walls, based on vulnerability functions, which consider structural and building matters of the Colombian environment.

\section{Vulnerability functions}

A vulnerability function is a mathematic relation that shows in a continuous way the damage that a specific structure may suffer at a determined level of seismic load. The vulnerability functions are deduced by a statistics regression of damage of the records observed or those intentionally produced. One of its main variables is derived from vulnerability functions that relate a vulnerability rate with a damage rate, conditioned by a parameter that describes the movement of field; this parameter may be the maximum acceleration $A_{a}$ or one of the seismic intensity scales such as MSK and MMI. 
Las funciones de vulnerabilidad pueden ser calculadas o definidas a través de datos observados (Caicedo et al., 1994). Las observadas se basan en información existente de registros de daño debidos a sismos, a diferencia de las calculadas, que dada la falta de esta información, simulan las características de las edificaciones para evaluar el daño.

Trabajos anteriores realizados (Maldonado et al., 2008 a, b y Maldonado y Chio, 2009) proponen funciones para las edificaciones de mampostería, de hormigón en sistema pórtico y de tierra. En el documento WP4 (Milutinovic y Trendafiloski, 2003) se presentan matrices de probabilidad de daño para edificaciones de muros en hormigón.

\section{Metodología para la construcción de las funciones de vulnerabilidad}

El procedimiento realizado para la definición de la función de vulnerabilidad en el presente trabajo, se basó en un análisis del comportamiento de las edificaciones ante la acción de un terremoto, a través del modelamiento estructural de una muestra representativa de las edificaciones de la ciudad de Bucaramanga en Colombia, realizando el siguiente procedimiento:

a) Recolección de información sobre aspectos arquitectónicos y estructurales a partir de planos estructurales y de visitas de campo.

b) Identificación de los parámetros que más influyen en la vulnerabilidad sísmica de estas edificaciones.

c) Generación de modelos a partir de la información recopilada. Algunos modelos fueron denotados como reales dado que dependieron totalmente de la información de los planos y otros se Ilamaron hipotéticos o simulados debido a que fueron construidos variando algunas características de los reales. De esta forma se pretendió representar la variación de las características de las edificaciones de este tipo estructural.

d) Cuantificación de la vulnerabilidad de cada edificación a través de un índice de vulnerabilidad a partir de la adaptación de la metodología propuesta por Benedetti y Petrini (1984).

e) Análisis no lineal de cada modelo, incorporando las rotulas de cortante y la interacción momento - carga axial.

f) Cálculo de un índice global de daño para cada edificación, ante diferentes solicitudes sísmicas, utilizando la metodología propuesta en el WP4 (Milutinovic y Trendafiloski, 2003).
The vulnerability functions may be calculated or defined through the observed records (Caicedo et al., 1994). The records observed are based on real information about damages produced by earthquakes, while the calculations, given the lack of information, simulate the building features to assess damage.

Previous researches (Maldonado et al., 2008 a, b y Maldonado y Chio, 2009) suggest functions for masonry buildings, and frame based concrete systems. The paper WP4 (Milutinovic and Trendafiloski, 2003) shows probability matrix for damages in buildings with of concrete walls.

\section{Methodology for building vulnerability functions}

The process to define the vulnerability function was based - in this research - on the analysis of the building behaviour in earthquakes; through a structural model of a representative sample at the city of Bucaramanga at Colombia, with the following steps:

a) Collecting records about architectural and structural matters from structural maps and field visits.

b) Identifying the parameters that most influence the seismic vulnerability on these buildings.

c) Producing models with the information obtained. Some models were considered real because they were completely dependant of plans, some others were hypothetical or simulated because they were built changing some features of the real ones. This was the way to pretend representing the building features of this structural type.

d) Quantifying the vulnerability of each building through a rate of vulnerability through an adjustment methodology suggested by Benedetti and Petrini (1984).

e) Non-linear analysis of each model, incorporating shear hinges and the moment axial load interaction.

f) Calculating a global damage rate for each building, in case of different seismic loads, using the methodology suggested in WP4 (Milutinovic and Trendafiloski, 2003). 
g) Relación de los valores del índice de vulnerabilidad con el índice de daño para cada acción sísmica definida, y con ellos definición de las funciones de vulnerabilidad.

\section{Muestra de edificaciones para la construcción de funciones}

La muestra sobre la que se construyeron las funciones de vulnerabilidad la conformaron 38 edificaciones construidas en muros de hormigón, 32 corresponden a reales y 6 definidas a partir de las reales, las cuales se les llamó hipotéticas o simuladas; ver Tabla 1. En esta tabla se identifica cada una por un número y se indica el tipo de modelo generado; el real es elaborado a partir de información existente de planos y complementado con visitas de campo, el hipotético es simulado a partir de uno real con variaciones de sus propiedades. A su vez, en la tabla se describe el periodo de construcción de la edificación de manera que ofrezca una indicación acerca del código de construcción utilizado en su diseño y construcción, el número de pisos y el área en planta. g) Relating values of vulnerability rate and damage rate in each seismic action and with that defining the vulnerability function

\section{Sample of buildings for function formulations}

The sample used to formulate vulnerability functions considers 38 buildings with concrete walls, 32 were real and 6 derived from the real ones, which were called hypothetical or simulated; see Table 1 . This Table 1 represents each one by a number and the kind of model produced; the real one used the information of plans, complementing it with field visits; the hypothetical one is simulated from a real one with changes in its properties. At the same time, this Tabla describes the building age in such way of providing a reference about construction code used in its design, quantity of floors and plant area.

Tabla 1. Muestra de edificaciones de muros de hormigón Table 1. Sample of buildings with concrete walls

\begin{tabular}{|c|c|c|c|c|}
\hline$\#$ & Tipo de modelo/ Model type & Año/Year & \# Pisos/Stories & Área/Area $\left(\mathrm{m}^{2}\right)$ \\
\hline 1 & Real & $1984-1998$ & 11 & 286 \\
\hline 2 & Real & $1984-1998$ & 11 & 172 \\
\hline 3 & Real & $1984-1998$ & 12 & 94 \\
\hline 4 & Real & $1984-1998$ & 12 & 187 \\
\hline 5 & Real & $1984-1998$ & 12 & 199 \\
\hline 6 & Real & $1984-1998$ & 5 & 92 \\
\hline 7 & Real & $1984-1998$ & 5 & 178 \\
\hline 8 & Real & $1984-1998$ & 5 & 66 \\
\hline 9 & Real & $1984-1998$ & 5 & 122 \\
\hline 10 & Real & $1984-1998$ & 11 & 74 \\
\hline 11 & Real & $>1998$ & 9 & 265 \\
\hline 12 & Real & $>1998$ & 9 & 110 \\
\hline 13 & Hipotético/Hypothetical & $>1998$ & 9 & 265 \\
\hline 14 & Hipotético/Hypothetical & $>1998$ & 9 & 110 \\
\hline 15 & Real & $1984-1998$ & 6 & 215 \\
\hline 16 & Hipotético/Hypothetical & $1984-1998$ & 6 & 215 \\
\hline 17 & Real & $1984-1998$ & 6 & 89 \\
\hline 18 & Real & $1984-1998$ & 6 & 354 \\
\hline 19 & Real & $1984-1998$ & 5 & 155 \\
\hline 20 & Real & $>1998$ & 6 & 314 \\
\hline 21 & Real & $1984-1998$ & 6 & 175 \\
\hline 22 & Real & $1984-1998$ & 5 & 72 \\
\hline 23 & Real & $1984-1998$ & 5 & 144 \\
\hline 24 & Hipotético/Hypothetical & $1984-1998$ & 12 & 199 \\
\hline 25 & Real & $1984-1998$ & 5 & 93 \\
\hline 26 & Real & $1984-1998$ & 5 & 93 \\
\hline 27 & Real & $1984-1998$ & 5 & 64 \\
\hline 28 & Real & $1984-1998$ & 5 & 238 \\
\hline 29 & Real & $<1984$ & 5 & 186 \\
\hline 30 & Real & $1984-1998$ & 5 & 93 \\
\hline 31 & Hipotético/Hypothetical & $>1998$ & 12 & 286 \\
\hline 32 & Hipotético/Hypothetical & $<1984$ & 12 & 286 \\
\hline 33 & Real & $1984-1998$ & 5 & 133 \\
\hline 34 & Real & $1984-1998$ & 5 & 212 \\
\hline 35 & Real & $1984-1998$ & 5 & 61 \\
\hline 36 & Real & $1984-1998$ & 5 & 118 \\
\hline 37 & Real & $1984-1998$ & 5 & 129 \\
\hline 38 & Real & $1984-1998$ & 6 & 116 \\
\hline
\end{tabular}




\section{Construcción de los modelos de las edificaciones}

En el análisis de una acción sísmica sobre una estructura, es imprescindible, en primera instancia, contar con una descripción del edificio mediante un modelo estructural. Es indispensable que la elección del modelo dependa en gran manera de las características de la estructura, la información que se posea sobre la misma, el nivel de aproximación deseado y las facilidades de cálculo disponible. Sin embargo, a pesar del esfuerzo en la consecución de la información de la edificación, ella por sí sola no garantiza que sea la completa y la necesaria para la elaboración de un modelo complejo del edificio: pues los mejores modelos serán aquellos que, siendo sencillos, asimilan la mayor cantidad de información posible.

En la construcción de las funciones de vulnerabilidad para edificios en muros de hormigón, los modelos se generaron en elementos unidimensionales, cada muro se idealizó como un elemento unidimensional representado en el centroide de la sección. A cada muro se le asignó la sección transversal junto con las propiedades del material en lo referente al hormigón y el acero; a su vez, a cada muro se le asociaron rotulas definidas para elementos tipo columna que combinan la interacción entre la carga axial y el momento en los sentidos principales. Debido a que en las edificaciones en muro el efecto predominante es el cortante interactuando con el momento, se aplicó la rotula de cortante, la cual fue construida para cada edificación en particular.

Para los modelos construidos, con elementos unidimensionales, la placa se representó considerando el aporte de su rigidez a la estructura, pero ignorando su posible falla. Luego la placa se modeló como un diafragma rígido, definiéndole a cada muro una zona rígida con un factor de efectividad igual a uno (1.0).

\section{Metodología para la evaluación del índice de vulnerabilidad}

El modelo utilizado para la estimación de la vulnerabilidad dentro de la construcción de las funciones de vulnerabilidad para edificaciones de muros en hormigón, se basa en la metodología del índice de vulnerabilidad, propuesta por los investigadores Benedetti y Petrini (1984).

El método del índice de vulnerabilidad está fundamentado en datos reales y es aplicable a estudios de nivel urbano en edificaciones de mampostería no reforzada y hormigón. Este modelo ha sido aplicado en otros estudios como en Yepez (1996), Mena (1999),

\section{Building construction models}

In the analysis of a seismic action over an structure, first of all, is essential to describe the building through an structural model. It is crucial that the model choice be highly dependant to the structure features, the information about its structure, the desired approximation level and the available computing capabilities. Nevertheless, besides the effort to obtain the building information, this by itself is no guarantee to have the complete and the required data to formulate a complex model of the building; thus the best models would be those that, besides of being simple, contain the largest quantity of information available.

In the formulation of vulnerability functions for buildings with concrete walls, the models were produced in one-dimensional elements, each wall was idealized as a one-dimensional element represented at the centroid of the section. Each wall was assigned with a transverse section with the material properties in regard to concrete and steel; by its side each wall was associated with defined hinges for elements as columns that mixed the axial load and the moment in the main orientations. Due that shear, in interaction with the moment was the predominant effect in walls, it was used a hinge shear for each building in particular.

For those models built with one-dimension elements, the slab was represented considering the contribution of its stiffness to the structure, but ignoring its possible failure. Later the slab was shaped as a rigid diaphragm, defining each wall with a rigid zone considering an effectiveness rate equal to one (1.0)

\section{Methodology to assess the vulnerability rate}

The model used to estimate the vulnerability in the formulation of vulnerability functions for concrete walls, is based in the methodology of rate vulnerability suggested by Benedetti and Petrini researchers (1984).

The method for the vulnerability rate is based on real records and is applicable to research on urban buildings with non reinforced masonry and concrete. This model has been used in researches as Yepez (1996), Mena (1999), 
Jiménez (2002), Gent et al. (2005), Maldonado et al. (2008) a, b y Maldonado y Chio (2009).

En la presente investigación la metodología se adaptó a las características propias de las edificaciones en las ciudades colombianas; correspondiendo las modificaciones básicamente, a la inclusión y exclusión de algunos parámetros y definición de la calificación y el valor de importancia de cada uno. El modelo se basa en la identificación de los parámetros de la estructura que mayor influencia tienen en su respuesta sísmica. A continuación se expone brevemente los parámetros considerados en el modelo.

6.1 Parámetros del modelo de índice de vulnerabilidad. El método para la evaluación de la vulnerabilidad de una edificación de muros se cuantifica a partir de trece (13) parámetros que representan la propensión de una edificación de muros a sufrir daño debido a un evento sísmico.

Los parámetros considerados son:

1. Sistema estructural.

2. Año de construcción.

3. Calidad del sistema resistente.

4. Resistencia convencional.

5. Posición de la edificación y la cimentación.

6. Suelo y pendiente.

7. Diafragma de piso.

8. Configuración en planta.

9. Configuración en altura.

10. Conexión entre elementos críticos.

11. Elementos no estructurales.

12. Estado de conservación.

13. Edificaciones adyacentes.

Cada parámetro a su vez se subdivide en tres o cuatro categorías cada una de ellas con un grado de vulnerabilidad diferente en menos vulnerable (A), medianamente vulnerable (B) y muy vulnerable (C) o absolutamente vulnerable (D). Por ejemplo, el parámetro doce (12) correspondiente al Estado de conservación se divide en tres categorías:

A) Edificación que se encuentra en buenas condiciones, sin fisuras de los elementos estructurales o daños en la cimentación.

B) Edificios que no clasifican como $\mathrm{A}$ o $\mathrm{C}$.

C) Edificación que presenta más de un $30 \%$ de elementos del sistema resistente fisurados, daños en la cimentación y la placa cuenta con fisuras mayores a $5 \mathrm{~mm}$.
Jiménez (2002), Gent et al. (2005), Maldonado et al. (2008) a, b y Maldonado y Chio (2009).

The present research shows a methodology that was adjusted to the typical features in the Colombian buildings; basically some changes refer to adding or excluding certain parameters and defining the qualification and the significant value for each one. The model is based on defining the structure parameters that most influence a seismic reaction. The following paragraph shows briefly the parameters considered in the model.

6.1 Parameters of the Vulnerability Rate Model The method to assess the vulnerability of walls is quantified by thirteen (13) parameters that represent the tendency of a building to suffer damage in a seismic event.

The parameters considered are:

1. Structural system.

2. Year of construction.

3. Quality of the structural system.

4. Conventional strength.

5. Position of the building and foundation.

6. Floor and slope.

7. Floor diaphragm.

8. Configuration in plant.

9. Configuration in height,

10. Connection between critical elements, 11. Non structural elements,

12. Preservation state,

13. Adjacent buildings.

Each parameter, by its side, is subdivided in three or four classifications each one with different vulnerability levels; less vulnerable (A) some vulnerable (B) and very vulnerable (C) or absolutely vulnerable (D). For instance the parameter twelve (12) belonging to the Preservation State is divided in three classifications:

A) A building in good conditions, without cracks in the structural elements or damage in foundations.

B) Buildings that do not fit in the classification of $\mathbf{A}$ or $\mathbf{C}$.

C) A building that has more than a $30 \%$ of cracks in the strength system, damages in foundation and the slab has cracks over $5 \mathrm{~mm}$. 
La asignación del grado de vulnerabilidad de cada categoría dentro del parámetro, se realizó a partir de la opinión de expertos en el tema recopiladas por medio de encuestas (Maldonado y Chio, 2008). Dada la subjetividad y ambigüedad en las opiniones de los expertos, estas fueron representadas por medio de números difusos. En la Figura 1 se presentan los grados de vulnerabilidad para el parámetro 12. A su vez, cada parámetro tiene un grado de importancia diferente.
The assignation of the level of vulnerability for each classification within the parameter was based on the experts' opinion and collected by surveys (Maldonado and Chio, 2008). Due to the subjectivity and ambiguity in their opinions, these were represented by fuzzy numbers. Figure 1 shows the level of vulnerability for parameter 12. By its side each parameter has different levels of significance.

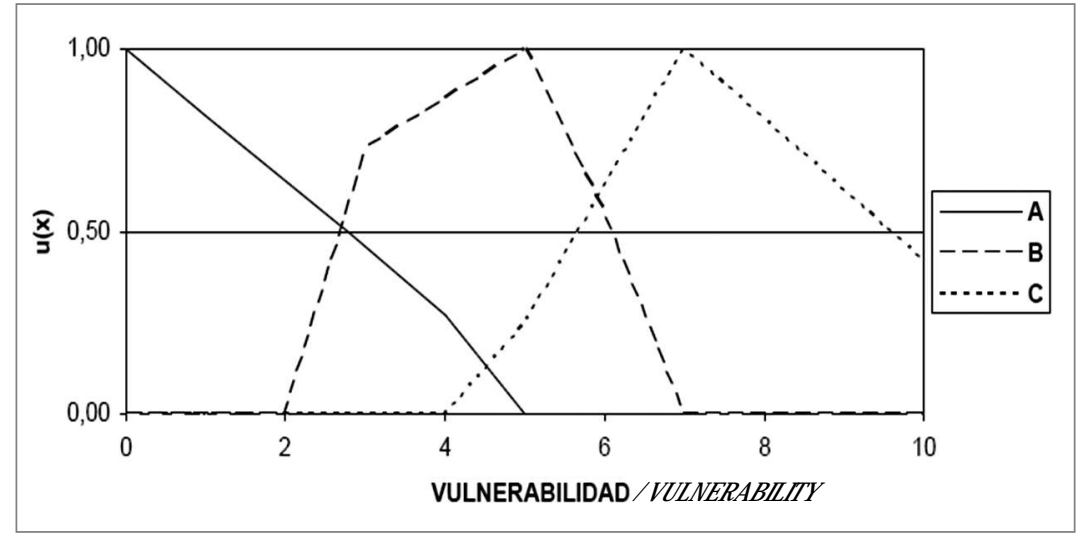

Figura 1. Grados de vulnerabilidad del parámetro 12 correspondiente al estado de conservación de la estructura Figure 1. Vulnerability levels for parameter 12 upon the structure preservation state

Así mismo, a cada parámetro se le definió un valor de importancia (peso) dentro de la definición de la vulnerabilidad total de la estructura, igualmente, por medio de las opiniones de expertos.

\subsection{Definición del índice de vulnerabilidad}

La evaluación del índice de vulnerabilidad se fundamenta en la calificación de los grados de vulnerabilidad y el peso de cada uno de los parámetros, definida a partir de opiniones de expertos. Debido a las imprecisiones e incertidumbre que genera este tipo de información se optó por la aplicación de matemática de conjuntos difusos (Zadeh (1965), Terano et al. (1992), Bandemer y Gottwald (1996)). La operación difusa que se utilizó en este proceso fue el Promedio Ponderado Difuso, y se expresa de la siguiente forma:
Thus, also through the experts' opinion, each parameter received a value of significance (weight) within the definition of the total structure definition.

\subsection{Definition of the vulnerability rate}

The assessment of the vulnerability rate according to the definition of experts- is based in the levels of vulnerability, and the weight of each parameter. Due to the lack of accuracy, and the uncertainty that produces this kind of information, the mathematic application of fuzzy sets was preferred (Zadeh (1965), Terano et al. (1992), Bandemer y Gottwald (1996)). The diffuse operation used in this process was the Diffused ponderated average, and its expression is the following:

$$
I . V=\frac{\sum_{i=1}^{11} K_{i} W_{i}}{\sum_{i=1}^{11} W_{i}}
$$


Donde IV es el índice de vulnerabilidad sísmica de la edificación en muros de hormigón, $K_{\mathrm{i}}$ es el valor del grado de vulnerabilidad de la edificación en el parámetro i. El valor $W_{i}$ es el peso del parámetro $i$ con respecto a los otros parámetros que influyen en la vulnerabilidad y es la forma de relacionarlos entre sí.

A partir de la evaluación realizada anteriormente y después de un proceso de lógica difusa se obtiene como resultado una calificación de la edificación en variables lingüísticas entre nada, poco, medianamente, muy y absolutamente vulnerable; ver Figura 2, a la cual se le asocia un valor numérico y una función de pertenencia que representa la ambigüedad de la respuesta.
Where $I V$ is the seismic rate of vulnerability in concrete walls, $K_{\mathrm{i}}$ is the added value of the building level of vulnerability in the parameter $i$. The value $W_{i}$ is the weight of parameter in regard to other parameters that influence the vulnerability and is the way how to relate them.

From the previous assessment and after a process of fuzzy logic, the result obtained is building qualification in linguistic variables among, nothing, few, some, very and absolutely vulnerable; see Figure 2, which is associated with a numeric value and a membership function that represents the answer ambiguity.

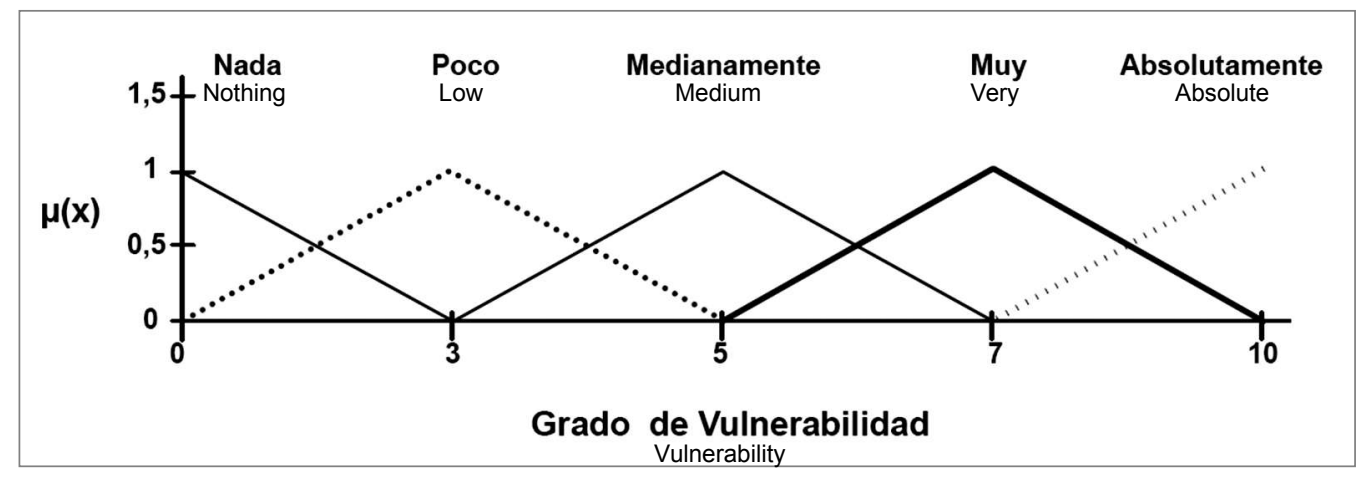

Figura 2. Función de pertenencia de las variables lingüísticas utilizadas

Figure2. Membership function of the linguistic variables used

\section{Metodología para la evaluación del índice de daño}

La metodología para determinar el daño en edificaciones de muros de hormigón se basa en la metodología LM2 propuesta en el proyecto Risk EU WP4 (Milutinovic y Trendafiloski, 2003). Esta metodología se fundamenta en el desarrollo de modelos que permiten determinar la capacidad y la demanda sísmica esperada de una edificación ante un determinado grado de amenaza sísmica.

La metodología propuesta en el WP4 condensa varias aplicaciones realizadas en Europa por diferentes centros de investigación como IZIIS, UTCB, CIMNE, AUTh y UNIGE. El método se aplicó para edificaciones en hormigón reforzado, y en algunos casos para edificaciones en mampostería. En el cual se relaciona la excitación sísmica y el daño de la edificación mediante la probabilidad de distribución de daño para una intensidad sísmica específica.

\subsection{Descripción del método}

El método requiere de un modelo de la edificación que representa las características de diseño,

\section{Methodology to assess the damage rate}

The methodology to determine damage in concrete walls is based on the methodology LM2 suggested in project Risk EU WP4 (Milutinovic y Trendafiloski, 2003). This methodology is founded in the development of model that allow to determine the capacity and seismic demand expected at a determine level of seismic threaten.

The methodology suggested in WP4 contains several applications used in Europe by different research centers as IZIIS, UTCB, CIMNE, AUTh y UNIGE. This method was used with buildings made of reinforced concrete, and in some cases to masonry constructions. This relates the seismic excitation and the building damage through the probability of damage distribution in a determined seismic intensity.

\subsection{Description of the Method}

This method requires a model of the building that represents features of design, 
construcción, fluencia y nivel último de su comportamiento. El modelo se somete a un análisis no lineal estático para obtener su capacidad o curva de capacidad (curva Pushover) y se relaciona con una demanda la cual se representa en un espectro. La curva de capacidad asocia el desplazamiento máximo de la cubierta con el cortante actuante en la base de la estructura. La respuesta máxima de la estructura, se estima en el punto de comportamiento, el cual es la intercepción entre el espectro de demanda y la curva de capacidad. Este punto de comportamiento refleja a partir de rangos de desplazamiento los estados de daño de la edificación.

La intersección de las dos curvas se realiza en el sistema de coordenadas ADRS el cual representa la aceleración espectral en el eje de las ordenadas, y el desplazamiento espectral en el eje de las abscisas (ATC40 1996).

\subsection{Estimación de la demanda}

En el estudio se utilizó el espectro de aceleraciones propuesto en la Norma Sismo Resistente Colombiana NSR98 (AIS-1998) que está asociado con la aceleración pico efectiva del terreno, $A_{a}$, ver Figura 3. El parámetro $A_{a}$ se define como el nivel de amenaza sísmica de la zona, tal que hay una probabilidad del $10 \%$ de que sea excedida en un lapso de 50 años según la NSR-98. Según el estudio realizado por la Asociación de Ingeniería Sísmica en Colombia, AIS, en el documento NSR-98 y dado que el estudio se realizó a las edificaciones de la ciudad de Bucaramanga, los parámetros necesarios para la construcción del espectro son: a) la aceleración pico efectiva para Bucaramanga igual a $0.25 \mathrm{~g}$, b) el coeficiente de importancia de la estructura I igual a uno (1), y c) el coeficiente del suelo del sitio $S$ se asumió como uno (1). Según los objetivos del proyecto se seleccionaron 6 escenarios asociados a 6 niveles de $A_{a}$ los cuales permitieron simular funciones de vulnerabilidad entre $0.05 \mathrm{~g}$ a $0.30 \mathrm{~g}$. construction, yield and the last level of behaviour. The model is subjected to a non linear static analysis in order to obtain its capacity or curve of capacity (Pushover curve), and is related to a demand that is represented in a spectrum. The curve of capacity is associated to the maximum movement of the top with the shear acting in the foundation of the structure. The maximum reaction of the structure is estimated in the behaviour point, which is the interception between the demand spectrum and the curve of capacity. This behaviour point shows the building damage state from movement rates.

The interception between the two curves is done in the ADRS system of coordinates, which represents the spectrum acceleration in the ordinate axis, and the spectrum movement in the abscises axis (ATC-40 1996).

\subsection{Demand estimation}

In the research the acceleration spectrum used was the norm Norma Sismo Resistente Colombiana NSR98 (AIS-1998), which is associated to the pick effective acceleration on field, $A_{a}$, see Figure 3 . The $A_{a}$ parameter is defined as the level of seismic threaten in the zone, thus there is a $\mathbf{1 0} \%$ probability of being exceded in a period time of 50 years, in reference to NSR-98. The parameters needed for the spectrum construction according to the research done by the Asociación de Ingeniería Sísmica de Colombia, AIS, in the paper NSR98, and given the fact that the research was made in the buildings near the city of Bucaramanga - are: a) the peack effective acceleration for Bucaramanga equal to a $0.25 \mathrm{~g}$, b) the structure significant coefficient I equal to (1), and c) the coefficient in the floor of the area $S$ was assumed as one (1). According to the objectives of the project, 6 scenarios were chosen and associated to 6 levels of $A_{a}$ which allow simulating functions of vulnerability between $0.05 \mathrm{~g}$ and $0.30 \mathrm{~g}$.

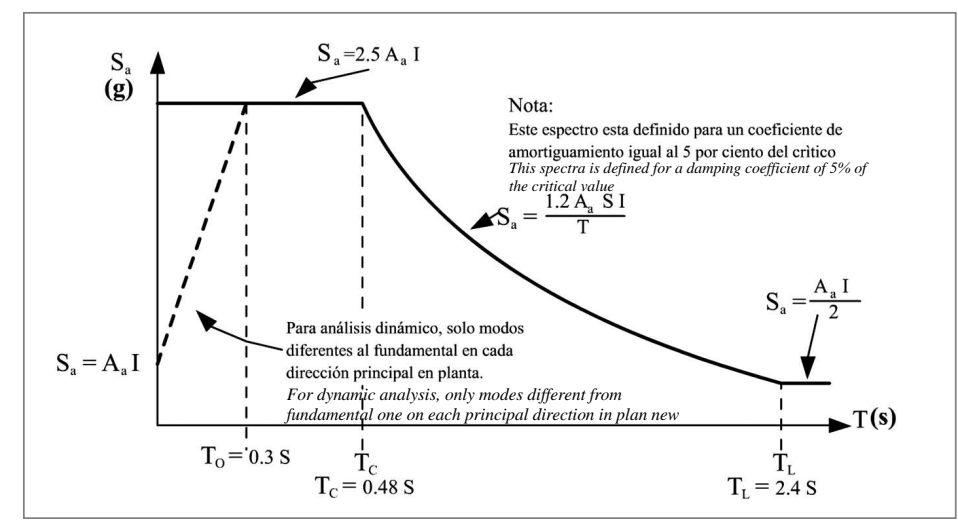

Figura 3. Espectro de respuesta utilizado (NSR-98)

Figure 3. Expected reaction spectra (NSR-98) 


\subsection{Curva de capacidad}

El modelo de capacidad se basa en la curva de capacidad, la cual relaciona la resistencia a carga lateral de la estructura representada por el cortante en la base, $\mathrm{V}$, con el desplazamiento lateral o desplazamiento máximo de cubierta, $\Delta R$. Esta función posee dos puntos característicos que denotan el comportamiento de la estructura, el límite o capacidad de fluencia $\left(V_{y}\right)$, y el límite de colapso o capacidad última, $\mathrm{V}_{\mathrm{u}}$, ver Figura 4. El límite o capacidad de fluencia, $V_{y}$, es la resistencia a carga lateral antes que la estructura desarrolle la respuesta plástica o no lineal de alguno de sus elementos estructurales. La capacidad última, $\mathrm{V}_{\mathrm{u}}$, es la máxima resistencia de la estructura después de haber superado el estado plástico de los elementos estructurales y representa la perdida de la estabilidad del sistema o la deformación a partir de la cual no se cuenta con ninguna resistencia lateral. Cerca al punto de fluencia, la capacidad de la estructura se asume como una relación lineal de la rigidez; y el trayecto entre el punto de fluencia y el punto último considera que la estructura pasa de un estado esencialmente elástico a uno puramente plástico. Más allá del punto último se asume un remanente plástico de la estructura.

\subsection{Curve of capacity}

The model of capacity is based in the curve of capacity, which relates the lateral load strength represented by the shear in base, V, with the lateral or maximum top movement, $\Delta \mathbf{R}$. This function has two characteristic points that show the structure behaviour, the limit o yield capacity $\left(V_{y}\right)$, and the collapse limit or last capacity, $V_{u}$, see Figure 4. The limit or yield capacity, $V_{y}$, is the lateral load strength before the structure develops a plastic or no linear reaction of some of its structural elements. The last capacity, $\mathrm{V}_{\mathrm{u}}$, is the maximum structure strength after overcoming the plastic state of structural elements and represents the system loss of stability or the deformation from which there is no lateral strength. Near the point of yielding, the structure capacity is assumed as a stiffness linear relation, and the movement between the yielding point ant the ultimate point considers that structure goes from a state basically elastic to other simply plastic. A plastic remaining of the structure is assumed further the ultimate point.

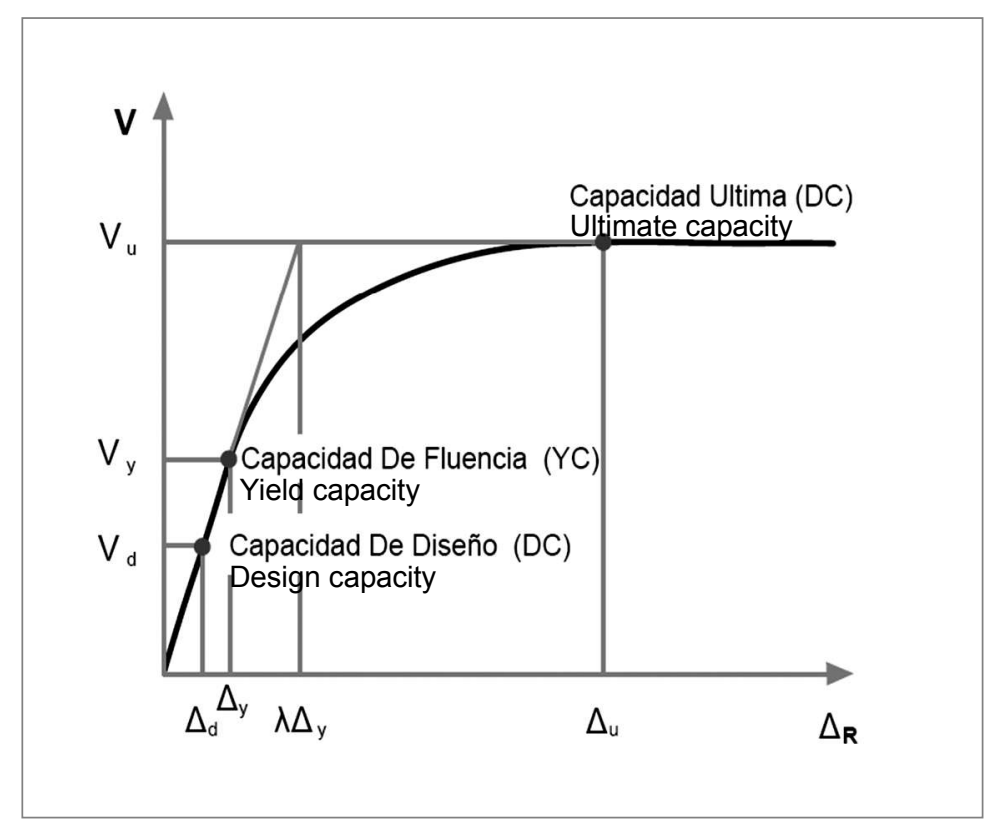

Figura 4. Modelo de capacidad de la edificación

Figure 4. Model of the building capacity 


\subsection{Estimación del punto de comportamiento}

Para la obtención del punto de comportamiento de la estructura ante una determinada acción sísmica se utilizó el método A descrito en el ATC-40. Este procedimiento se basa en un método iterativo donde se convierten las dos curvas al formato ADRS, se supone un punto de comportamiento inicial y se calcula un valor que toma en cuenta la energía histerética disipada por los elementos estructurales, determinada como una fracción del área bajo la curva de comportamiento. Luego se aplica en la reducción del espectro de respuesta si el punto de intercesión supuesto inicialmente es igual o con un error menor al 5\%, el punto obtenido al reducir el espectro es el punto de comportamiento de la estructura, como se muestra en la Figura 5.

\subsection{Estimation of the Behaviour Point}

To obtain the structure behaviour point in case of a determined seismic action the method A described in ATC-40 was used. This process based in an iterative method where the two curves are conversed into the ADRS format, an initial behaviour point is supposed and a calculated value considers the hysteric energy dissipated by structural elements, determined as proportion of the area under the behaviour curve. Then the reaction spectrum is reduced if the supposed intersection point is equal o has a variation less than a $5 \%$, the point obtained at reducing the spectrum is the structure behaviour point, as shown in Figure 5.

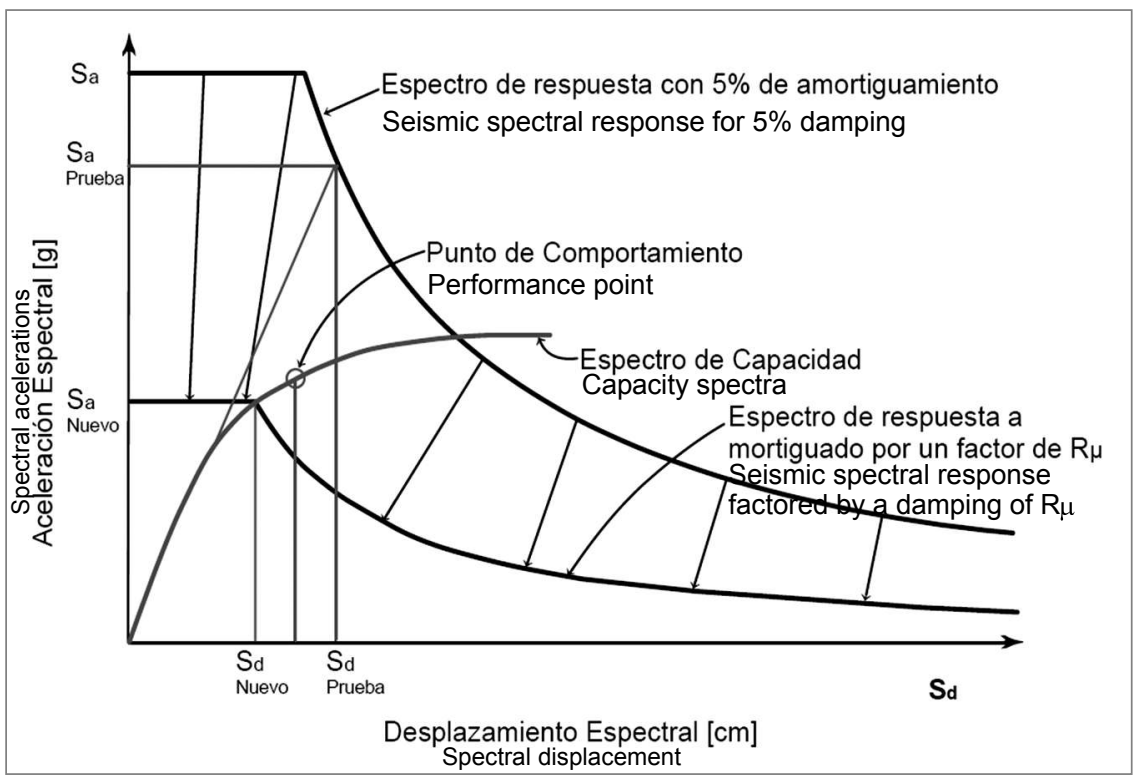

Figura 5. Procedimiento general para el punto de comportamiento de acuerdo al ATC-40

Figure 5. Procedimiento general para el punto de comportamiento de acuerdo al ATC-40

\subsection{Procedimiento para la evaluación del daño}

La finalidad de la evaluación del daño de una edificación o grupo de edificaciones es estimar el nivel de afectación que permita cuantificar las pérdidas tanto económicas como humanas que producen el sismo. En este trabajo la determinación del daño se basó en un análisis no lineal estático (Pushover). Este procedimiento posee algunas ventajas para su aplicación dado que no necesita el desarrollo de un registro sísmico y no requiere considerar el comportamiento de histéresis de la estructura; y a partir de rangos de desplazamientos máximos de cubierta se estima el estado de daño que pude presentar la edificación.

\subsection{Process to assess damage}

The aim of assessing a building or a group of them is to estimate the level of impact that will allow quantifying either economic or human loss produced in the earthquake. The damage classification, in this paper, was based on static non linear analysis (Pushover). This process has some advantages to be used because it does not need to develop a seismic register neither considering the structure hysteresis behaviour; and the damage state that the building may present can be estimated from the maximum movement rates of the top. 
Los rangos o estados de daño de una edificación son expresados comúnmente con expresiones lingüísticas que describen el estado del sistema estructural después de ser sometida a un sismo determinado y están asociados a inspecciones de edificaciones post-sismo. Para propósitos prácticos es normal describir de cuatro (4) a cinco (5) estados de daño. En esta investigación los estados de daño utilizados para la generación de la curvas de vulnerabilidad están basados en los propuestos por la metodología LM2 (Milutinovic y Trendafiloski, 2003) y, son los siguientes: Ninguno, Menor, Moderado, Severo y Colapso, ver la Tabla 2.

La definición de los niveles de daño de la estructura se realizó a partir de la implementación de los intervalos de desplazamientos que propone el WP4 Risk EU (Milutinovic y Trendafiloski, 2003) en el método LM2, ver la Tabla 3. El desplazamiento de la cubierta corresponde al espectral $\left(\mathrm{S}_{\mathrm{d}}\right)$ y según la fuente esta denotado por la letra $\mathrm{D}$. Los límites de desplazamiento de la Tabla 3 están en función del parámetro $D$ que es el desplazamiento de la cubierta en coordenadas espectrales dado por el punto de comportamiento, y permite en función del desplazamiento asociarle un rango de daño a la edificación. Estos rangos de daño están delimitados por $D_{y}$ que es el desplazamiento en la cubierta en el punto de fluencia de la estructura, y $D_{u}$ que es el desplazamiento en el punto último.
The rates or damage state of a building usually are linguistically expressed describing the state of the structural system after being affected by a determined earthquake and are associated to post-earthquake buildings examinations. These damages are usually classified for practical use from four (4) to five (5) states of damage. In this research the damage states used to form the vulnerability curves are based in the LM2 methodology proposal (Milutinovic y Trendafiloski, 2003) as the following: any, minor, moderated, serious, and collapse, see Table 2 .

The definition of the structure damage level was done from the implementation of movement intervals suggested in WP4 Risk EU (Milutinovic y Trendafiloski, 2003) and the method LM2, see Table 3 . The movement of the top belongs to spectrum I $\left(S_{d}\right)$ and according to the source is indicated by the letter $D$. The movement limits in Table 3 are in function of parameter $D$, which is the movement of the top in the spectral coordinates, given the behaviour point, and it allows associating a building damage rate in function of the movement. These damage rates are limited by $D_{y}$, which is the movement of the top in the structure fluency point, and $D_{u}$ that is the movement in the ultimate point.

Tabla 2. Niveles de daño y su descripción

Table 2. Damage levels and its description

\begin{tabular}{|c|c|c||}
\hline $\begin{array}{c}\text { Grado de daño } \\
\text { Level of Dange }\end{array}$ & $\begin{array}{c}\text { Definición } \\
\text { Definition }\end{array}$ & $\begin{array}{c}\text { Descripción } \\
\text { Description }\end{array}$ \\
\hline 0 (DO) & Ninguno/Any & No daño/No damage \\
\hline $1(\mathrm{D} 1)$ & Menor/Minor & Daño insignificante a leve/Small to minor level of damage \\
\hline $2(\mathrm{D} 2)$ & Moderado/Moderated & Daño estructuralmente leve/Small structural damage \\
\hline $3(\mathrm{D} 3)$ & Severo/Serious & Daño estructuralmente moderado/Moderate structural damage \\
\hline $4(\mathrm{D} 4)$ & Colapso/Collapse & Daño estructuralmente fuerte/Strong structural damage \\
\hline \hline
\end{tabular}

Tabla 3. Grados de daño considerados según desplazamientos de la estructura (Milutinovic y Trendafiloski, 2003)

Table 3. Level of considered damages according to the structure movement (Milutinovic y Trendafiloski, 2003)

\begin{tabular}{||c|c|c|c||}
\hline $\begin{array}{c}\text { Grado de daño } \\
\text { Level of Damage }\end{array}$ & $\begin{array}{c}\text { Definición } \\
\text { Definition }\end{array}$ & $\begin{array}{c}\text { Límites de desplazamiento espectral } \\
\text { Spectral movement limits }\end{array}$ & $\begin{array}{c}\text { Índices de daño } \\
\text { Damage rates }\end{array}$ \\
\hline $0(D O)$ & Ninguno/Any & $D<0.7 D_{y}$ & 0 \\
\hline $1(D 1)$ & Menor/Minor & $0.7 \mathrm{D}<=\mathrm{D}<1.0 \mathrm{D}_{\mathrm{y}}$ & $0-5 \%$ \\
\hline $2(\mathrm{D} 2)$ & Moderado/Moderate & $1.0 \mathrm{D}<=\mathrm{D}<\mathrm{D}_{\mathrm{y}}+\mathrm{D}_{\mathrm{uy}}$ & $5-20 \%$ \\
\hline $3(\mathrm{D} 3)$ & Severo/Serious & $\mathrm{D}_{\mathrm{y}}+\mathrm{D}_{\mathrm{uy}}<=\mathrm{D}<\mathrm{D}_{\mathrm{u}}$ & $20-50 \%$ \\
\hline $4(\mathrm{D} 4)$ & Colapso/Collapse & $\mathrm{D}_{\mathrm{u}}<=\mathrm{D}$ & $50-100 \%$ \\
\hline \multicolumn{5}{|c|}{$\mathrm{D}_{\mathrm{uy}}=0.25\left(\mathrm{D}_{\mathrm{u}}-\mathrm{D}_{\mathrm{y}}\right)$} \\
\hline
\end{tabular}


Luego, los pasos desarrollados para la determinación del estado de daño que puede alcanzar una edificación son:

- Determinación de los parámetros que intervienen en el comportamiento sísmico de las edificaciones en el sistema estructural de muros de hormigón.

- Recolección de la información de una muestra.

- Generación de los modelos no lineales aplicando las rotulas de cortante y la interacción carga axial - momento.

- Construcción de la curva de capacidad para cada edificación de la muestra.

- Determinación del espectro de demanda para diferentes aceleraciones pico.

- Cálculo del punto de comportamiento de las edificaciones de la muestra, para todas las aceleraciones.

- Determinación del daño por medio de los rangos definidos en la Tabla 3.

\section{Establecimiento de las funciones de vulnerabilidad}

Las funciones de vulnerabilidad para edificaciones en sistema muros de hormigón reforzado, como se mencionó anteriormente, se generaron a partir de una muestra de 38 edificaciones ubicadas en la ciudad de Bucaramanga en Colombia. Para la muestra se evaluó el índice de vulnerabilidad con el programa IVEN (Maldonado y Chio, 2008) de cada edificación basado en la información recolectada sobre planos y en campo. Con los índices de vulnerabilidad se construyó un histograma de frecuencias relativo compuesto por los índices de vulnerabilidad de las edificaciones de la muestra, ver Figura 6 .

En la Figura 6 se observa que los índices de vulnerabilidad de las edificaciones de la muestra están entre 2.2 y 8.5, siendo el rango entre 2.2 y 4.3 en donde se ubican buena parte de ellas. Luego, las edificaciones de muros se clasifican entre poco y medianamente vulnerables.
Then, the steps developed to determine the state of damages that a building can reach are:

- Determination of the parameters that interact in the seismic behaviour of buildings that have concrete walls in its structural system.

- Collecting the sample information.

- Generating the non linear models using the shear hinges and the moment axial load interaction

- Formulating the capacity curve for the building of the sample.

- Determining the demand spectrum for the different pick accelerations.

- Calculating the building behaviour point in the sample, for all the accelerations.

- Determining the average damage through the ranges defined in Table 3.

\section{Formulating vulnerability functions}

The vulnerability functions for buildings with reinforced concrete walls were formulated, as mentioned before, through a sample of $\mathbf{3 8}$ buildings placed in the city of Bucaramanga at Colombia. The vulnerability rate for each building of this sample, was assessed with the program IVEN (Maldonado and Chio, 2008), based in the information collected from plans and field. The vulnerability rates were used to build a relative frequency histogram formed by the vulnerability of the buildings in the sample, see Figure 6.

The Figure 6 shows that the vulnerability rates of the buildings in the sample are between 2.2 y 8.5 , being the most of it in the range between 2.2 and 4.3. Then the walls are classified between few and regular vulnerable.

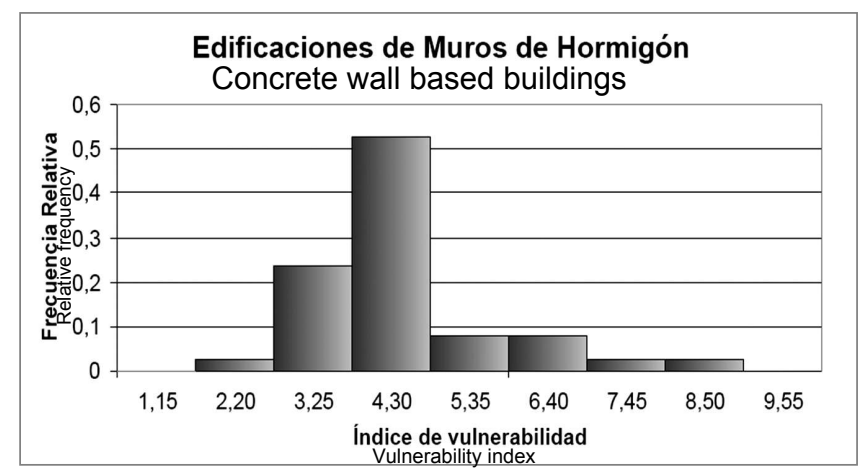

Figura 6. Histograma de frecuencias de los índices de vulnerabilidad obtenidos de los modelos Figure 6. Frequency histograms for the vulnerability rates obtained in models 
Luego a cada edificación se le estimó el daño para cada acción sísmica y se relacionó con el índice de vulnerabilidad, obteniendo como resultado las funciones de vulnerabilidad, donde el índice de vulnerabilidad se represente en las abscisas, y el índice de daño en las ordenadas para diferentes eventos sísmicos. En vista de la gran dispersión en algunas zonas, se optó por establecer intervalos de vulnerabilidad de $\mathbf{0 . 0 2}$, y se cálculo un índice de daño representativo de los daños de las edificaciones ubicadas y caracterizadas dentro de ese pequeño intervalo. De esta manera, se discretizarón convenientemente las funciones de vulnerabilidad, es decir, cada valor de índice de vulnerabilidad (abscisa) corresponde al valor promedio de su rango correspondiente de índices de vulnerabilidades, en tanto que su ordenada de daño asociada corresponde al promedio de los daños de las edificaciones dentro del intervalo considerado. De esta manera se presentan las funciones de vulnerabilidad para las edificaciones de muros de hormigón en la Figura 7.
Then each building had an estimation of damage for each seismic action and was related with the vulnerability rate, obtaining as result the vulnerability functions, where the vulnerability rate is represented in the abscises, and the damage rate on the ordinates for each different seismic event. As some areas were dispersed, the option was to set a vulnerability of 0.02 , and calculating the representative damage of buildings within that interval. Thus the functions of vulnerability were conveniently discretizated, that is to say that each value in the vulnerability rate axis belongs to the average value in its range according to the vulnerability rates, then the associated damage ordinate belongs to the building damage average within the interval considered. This is the way to represent the vulnerability functions for buildings with concrete walls, Figure 7

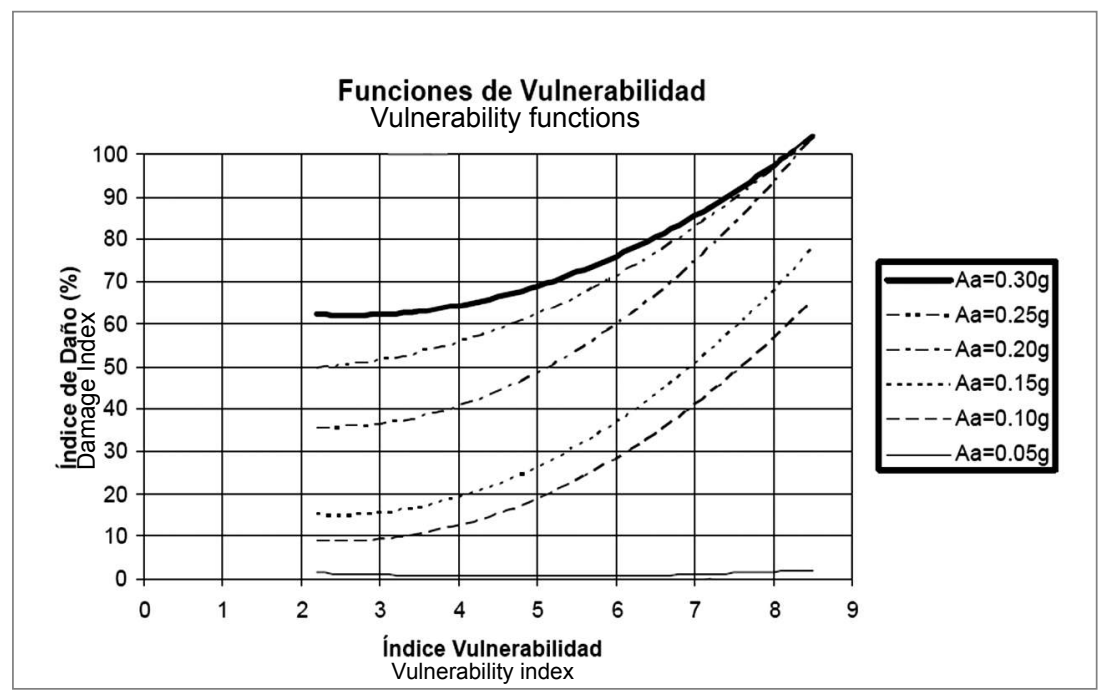

Figura 7. Función de vulnerabilidad calculada para diferentes valores de Aa

Figure 7. Function of vulnerability calculated for different values of Aa

La regresión que mejor se adapta a los datos se muestra a continuación:

The following is the regression that better fits to the records:

$$
D(\%)=a_{1} V^{2}+a_{2} V+b
$$

Los valores de las constantes $a_{1}, a_{2}$, y $b$ para cada una de las aceleraciones estudiadas se muestran en la Tabla 4.
Table 4 shows the values of the constant $a_{1}, a_{2}$, y $b$ for each acceleration observed. 
Tabla 4. Coeficientes de las funciones ajustadas Table 4. Coefficients of the adjusted functions

\begin{tabular}{|c|c|c|c||}
\hline \hline $\boldsymbol{A}_{\boldsymbol{a}}(\boldsymbol{g})$ & $\boldsymbol{a}_{\mathbf{1}}$ & $\boldsymbol{a}_{\mathbf{2}}$ & $\boldsymbol{b}$ \\
\hline 0.05 & 0.12 & -1.15 & 3.41 \\
\hline 0.10 & 1.55 & -7.67 & 18.23 \\
\hline 0.15 & 1.70 & -8.28 & 24.97 \\
\hline 0.20 & 1.80 & -8.43 & 45.36 \\
\hline 0.25 & 1.19 & -4.05 & 52.70 \\
\hline 0.30 & 1.21 & -6.27 & 70.12 \\
\hline
\end{tabular}

\section{Calibración de las funciones}

Los resultados obtenidos con el modelo fueron comparados con los obtenidos utilizando la metodología pospuesta en el WP4 Risk UE, la cual estima el daño considerando la acción sísmica por medio de la escala de intensidad de Mercalli Modificada. Por ello, fue necesario, para el cálculo del daño medio, determinar con anterioridad la relación entre aceleración pico efectivo e intensidad a partir de la expresión propuesta por Trifunac y Brady en 1975 expuesta en el ATC-13. Una vez, obtenidos los estimativos de daño por los dos métodos expresados en función de la aceleración, estos se compararon encontrándose similitudes en sus respuestas.

\section{Aplicación de las funciones}

Las funciones fueron aplicadas para estimar los daños que se pueden producir en las edificaciones de muros presentes en la meseta de Bucaramanga, ante dos posibles eventos sísmicos.

Los dos escenarios sísmicos pertenecen a la Falla Bucaramanga-Santa Marta y La Frontal, que corresponden a valores de aceleración máxima de $\mathbf{0 . 1 6 g}$ y $0.21 \mathrm{~g}$ respectivamente, los cuales a su vez pertenecen a los eventos utilizados en el estudio de Microzonificación Indicativa de Bucaramanga (INGEOMINAS, 2001).

La información de las edificaciones de la zona se recopiló a partir de encuestas realizadas a cada uno de los predios y mediante registros fotográficos. Luego los datos de cada edificación fueron incorporados en un sistema de información geográfico que facilitó el manejo y visualización de la información recopilada y de los resultados obtenidos.

Posteriormente, con la información se evaluó el índice de vulnerabilidad de cada uno de los predios; luego, con las funciones de vulnerabilidad simuladas se procedió a estimar el índice de daño para los dos escenarios sísmicos. En las Figuras 8 y 9 se muestran los resultados de índice de daño obtenidos para los dos escenarios sísmicos.

\section{Calibration of functions}

The results of the model were compared with those reached with the methodology suggested in WP4 Risk UE, which estimates the damage considering a seismic action through a modified Mercalli scale. Thus, first, the relation between the peak acceleration and intensity had to be determined, according to the expression suggested by Trifunac and Brady in 1975 at ATC-13, in order to calculate the average damage. Once that the both methods, in function of acceleration, produced results, they were matched finding similar answers.

\section{Function application}

The functions were used to estimate damages in the walls of the buildings at Bucaramanga in case of two eventual seismic situations.

The two seismic scenerios belongs to Bucaramanga-Santa Marta and La Frontal failures, where the maximum acceleration values are $0.16 \mathrm{~g}$ and $0.21 \mathrm{~g}$ respectively, which -by its side - correspond to the material used in the research at Microzonificación Indicativa de Bucaramanga (INGEOMINAS, 2001).

The information about buildings was obtained through surveys in each area and photographical records. Then the information of each building was registered into a geographical system that made easier to visualize and handle the information and results obtained.

Later, this information allowed assessing the vulnerability rate of each area; then the next step, with the simulated vulnerability functions, was to estimate the damage rate for the seismic scenerios. Figures 8 and 9 show the damage rates obtained to both seismic scenerios. 


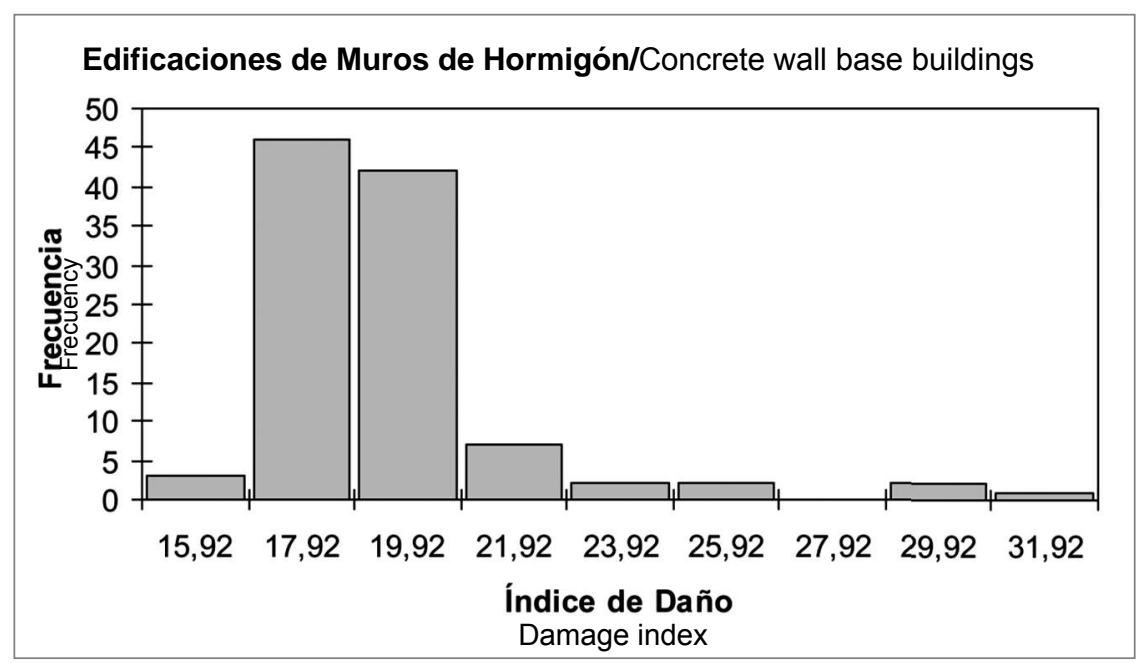

Figura 8. Estados de daños para edificaciones de muros en hormigón a una aceleración de $\mathbf{0 . 1 6} \mathrm{g}$

Figure 8. Damage state for buildings with concrete walls at an acceleration of $0.16 \mathrm{~g}$

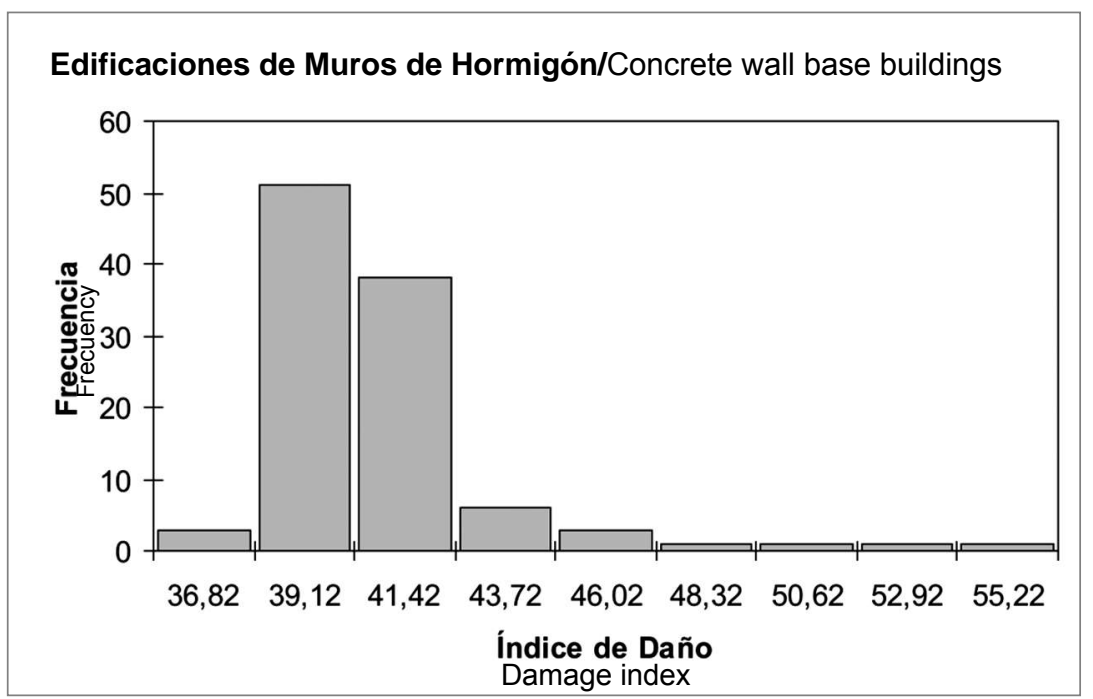

Figura 9. Estados de daños para edificaciones de muros en hormigón a una aceleración de $\mathbf{0 . 2 1 \mathrm { g }}$

Figure 9. Damage state for buildings with concrete walls at an acceleration of $0.21 \mathrm{~g}$

De los resultados obtenidos para la ciudad de Bucaramanga, se observa que los máximos daños alcanzados en los edificios de muros estructurales de hormigón para el primer escenario, son del $20 \%$ y para el segundo los daños alcanzan el doble, es decir, hasta el $40 \%$.

\section{Conclusiones}

- Mediante el presente estudio se proponen funciones de vulnerabilidad sísmica para edificaciones correspondientes al sistema de muros estructurales de hormigón armado.
The results obtained at Bucaramanga show that the maximum damage, in structural concrete walls at the first scenario, reached a $20 \%$ and the second obtained the double of damage, that is to say a $40 \%$.

\section{Conclusions}

- The present research suggests seismic vulnerability functions for buildings with structural walls made of reinforced concrete. 
Estas funciones fueron obtenidas mediante modelamiento de edificaciones reales e hipotéticas, de manera que no se requirió recurrir a datos o registros de daños reales. El modelo se basa en la definición de trece (13) parámetros, que son considerados como los de mayor incidencia en el comportamiento de la estructura ante la acción de un sismo. Cada uno de estos parámetros se divide en categorías a las cuales les asigna un grado de vulnerabilidad, y dentro del modelo se le define un grado de importancia a cada parámetro. Luego, a partir de los grados de vulnerabilidad y de los valores de importancia se introduce el método de índice de vulnerabilidad para evaluar la vulnerabilidad, el cual es eficiente para la evaluación de la vulnerabilidad a gran escala de edificaciones. Así mismo, el daño se estimó a partir de un análisis no lineal estático para diferentes escenarios de daño. Finalmente, se relacionaron los índices de vulnerabilidad con los de daño para los escenarios sísmicos definidos, y con ellos se construyeron las funciones de vulnerabilidad sísmica.

- La muestra de edificaciones utilizadas para la construcción de las funciones cuentan con las siguientes características: o Las plantas de las edificaciones de la muestran son cuadradas o rectangulares. Un $56 \%$ de ellas tienen, aproximadamente, $20 \mathrm{~m}$ de largo por $10 \mathrm{~m}$ de ancho, un $22 \%$ corresponden a plantas de $10 \mathrm{~m}$ por $10 \mathrm{~m}$, un $16 \%$ se asocia a aquellas de $30 \mathrm{~m}$ por $10 \mathrm{~m}$ y el $6 \%$ restante está representando en las edificaciones de aproximadamente $20 \mathrm{~m}$ por $20 \mathrm{~m}$.

o Con respecto al número de niveles de las edificaciones, un $68 \%$ cuentan con 5 a 6 pisos, un $11 \%$ con 9 pisos y un $21 \%$ corresponden a edificios de 11 a 13 pisos. o Alrededor del $70 \%$ fueron diseñadas y construidas entre 1984 y 1998, lapso de tiempo donde se implementó la primera Norma de Construcción Sísmoresistente en Colombia (Código Colombiano de Construcción Sismo Resistente, CCCSR-84). El resto corresponde a edificios construidos antes de 1984 y otros después del 1998, fecha a partir del cual se empezó la aplicación de la nueva Norma Colombiana de Diseño y Construcción Sismo Resistente, NSR-98. o En cuanto a la calidad del sistema resistente el $\mathbf{9 2 \%}$ de las edificaciones contaban con un hormigón de buena consistencia el cual se observaba que estaba bien ejecutado y con refuerzo corrugado bien colocado. Además, se observo que fueron elaborados empleando mano de obra adecuada y siguiendo con un proceso constructivo adecuado.
These functions were obtained by modelling real and hypothetical buildings, without the need to find real damage records. The model is based in thirteen (13) parameters, considered the most influent in the structure behaviour in case of a seismic action. Each parameter is divided into categories, each one is assigned with a vulnerability degree, and within the model each parameter is identified with a degree of significance. Thus the vulnerability and significant values give place to the vulnerability rate method, which is efficient to assess the vulnerability of buildings at large scale. The damage in different scenerios was estimated from a non linear static analysis. Finally, the vulnerability and damage rate of the defined scenerios were related to formulate the vulnerability seismic functions.

- The sample of buildings used to formulate functions has the following features:

o The plants of the building are squared or rectangular. A $56 \%$ of it is nearly $20 \mathrm{~m}$ de long and $10 \mathrm{~m}$ wide, a $22 \%$ corresponds to $10 \mathrm{~m} \times 10 \mathrm{~m}$ plants, a $16 \%$ is associated to those with a size of $30 \mathrm{~m} \times 10 \mathrm{~m}$ and a $6 \%$ remaining is represented in buildings with a near size of $20 \mathrm{~m} \times 20 \mathrm{~m}$.

o In regard to the number of floors, a $68 \%$ has 5 or 6, $11 \%$ has 9 and a $21 \%$ corresponds to buildings with 11 or 13 floors.

o Nearly the $70 \%$ was designed and built between 1984 and 1998, period of the first seismic Colombian code implementation (Colombian code of seismic resistant building, cccsr-84). The rest corresponds to buildings older than 1984 and other built after 1998, when the first Colombian seismic resistant code of building and design was implemented, nsr-98.

o In regard to the quality of the strength system, a $92 \%$ of the buildings had a good concrete with good buildings condition and reinforced corrugated in the right place. Furthermore it was observed the correct use of manpower and construction process. 
o En el $45 \%$ de las edificaciones se evidenciaron deficiencias en su resistencia a soportar la carga sísmica y esto en razón a la falta de muros en una dirección. La mayoría de las edificaciones están en capacidad de resistir las fuerzas sísmicas en la dirección de mayor aporte de área de los muros, pero en la otra dirección se pueden presentan deficiencias.

o El $75 \%$ de las edificaciones se encuentran cimentadas a una misma cota, sobre suelo estable con pendientes menores a $15 \%$.

o El $84 \%$ de las edificaciones presentaban diafragmas con deformabilidad despreciable y correctamente conectadas a los elementos verticales.

o En cuanto a la configuración en planta de las edificaciones tan solo el $30 \%$ presentan una planta regular sin problemas de irregularidad. o Más de la mitad de las edificaciones no presentan irregularidad en altura, pues en el $65 \%$ de las edificaciones o no existe disminución de área entre pisos o si se presenta es menor al $10 \%$ y, a su vez, no presentan cambios considerables en rigidez de un piso a otro. Las restantes cuentan con variaciones de masa o rigidez, los cuales llegan a ser preocupantes en el $30 \%$ de las edificaciones.

o Alrededor del $80 \%$ de las edificaciones cuentan con conexiones correctamente detalladas entre sus elementos.

o En solo el $25 \%$ de las edificaciones se presentan voladizos sosteniendo balcones, o existen tanques elevados en la parte superior los cuales pueden influir en el comportamiento de la estructura ante la acción sísmica.

o En cuanto al estado de conservación, tan solo un $15 \%$ registro alguna muestra de deterioro y falta de mantenimiento.

- En este trabajo, además, se estudió el comportamiento de los edificios de sistema de muros en hormigón, de Bucaramanga; a partir de la aplicación de las funciones de vulnerabilidad calculadas en esta investigación. Estas funciones permiten conocer el posible daño que puede sufrir un edificio de muros de hormigón ante un evento sísmico, dadas sus características estructurales y condiciones del sitio.

- La metodología propuesta en este trabajo abarca distintos aspectos de cálculo, cada uno de los cuales constituye un aporte a los modelos de evaluación de la vulnerabilidad y de daño estructural. El método involucra procedimientos de modelamiento de edificaciones reales e hipotéticas que revelan las características de las estructuras existentes en la ciudad de Bucaramanga y su Área Metropolitana. o The $45 \%$ of buildings showed deficient seismic load strength due to the lack of walls in one direction. Most of the buildings are able to resist seismic load in the area of more walls but in the other may present deficiencies.

o A $75 \%$ of the buildings are founded in the same line, over a stable land with slopes smaller than a $15 \%$.

o The $84 \%$ of the buildings presented unshaped diaphragms, and properly connected to vertical elements.

o Concerning to the configuration of plants only the $30 \%$ presented regular plants without problems.

o More than half of buildings do not present irregularities at height, because a $65 \%$ of them does not diminish the area between floors an if does, it is les than $\mathbf{1 0} \%$ $y$, by its side they do not show considerable problems in stiffness from one floor to the other. The rest show mass or rigidity changes, which in a $30 \%$ is significant.

o Nearly the $80 \%$ of buildings have properly detailed connections within its elements.

o Only the $25 \%$ of building have elements supporting balconies, or there are water recipients in the top area, which are factors to consider in the structure behaviour in case of a seismic action.

o Concerning to the preservation state, only a $15 \%$ have shown a signal of lack of maintenance or deterioration.

- This paper besides, considered the study of behaviour in buildings with concrete walls in Bucaramanga from the use of the vulnerability functions of this research. These functions make possible to know the eventual damage that a building with concrete walls may have in case of a seismic event, given its structural features and the field conditions.

- The methodology suggested in this paper embraces different aspects of design; each one contributes to the vulnerability model and structural damage assessment. The method considers a modelling process for hypothetical and real edifications which shows the features of the structures that are in the city of Bucaramanga and in its metropolitan area. 
Además, el modelo involucra procedimientos para la calificación del índice de vulnerabilidad como mecanismo de calificación del estado estructural.

- Las funciones de vulnerabilidad fueron comparadas con las construidas en el proyecto WP4 Risk EU, encontrándose similitud entre los resultados obtenidos por los dos métodos.

- En la ciudad de Bucaramanga el sistema muros de hormigón representa el $\mathbf{4 1 . 8 3} \%$ de las edificaciones de hormigón. Es decir que es uno de los más utilizados y su crecimiento se ha incrementando después de la implementación de la norma NSR-98. Dado los resultados y comparados con los obtenidos en el sistema de edificaciones de pórtico o mampostería (Maldonado et al., 2008) los niveles de daño para los dos probables escenarios sísmicos de la ciudad son menores.

- Durante la generación de los modelos de la muestra de edificaciones se observó la deficiencia de muros en el sentido paralelo a la fachada como propia de este tipo de edificaciones. Lo anterior no es evidente durante la recolección visual de la información en campo, solo se identifica durante un estudio sobre planos de las edificaciones.

- Un problema detectado durante la recolección visual de información es la falta de separación de edificaciones adyacentes; el cual se hace más preocupante con la existencia de placas a diferentes niveles entre ellas, dado que esto genera grandes fuerzas cortantes por el golpeo de las estructuras durante un sismo.

- Analizando los resultados de las calificaciones de los parámetros del modelo en la muestra de edificaciones se observa que en su mayoría se califican entre A y B, el cual corresponden a los de grados que representan el menor grado de vulnerabilidad, de aquí que finalmente las edificaciones estén dentro del rango de poco a medianamente vulnerable. Sin embargo, los parámetros que influyeron negativamente están representados en la deficiencia en el tercer parámetro (Resistencia convencional) dado la deficiencia en la configuración de los muros al predominar su ubicación en una sola dirección, y al no aportar a la estructura igual rigidez en las dos direcciones. Este aspecto se evidencia en el porcentaje de área de muros en la dirección más débil con respecto al área total de muros, pues en el $\mathbf{4 2} \%$ de las edificaciones de la muestra el porcentaje de área de muros en una sola dirección está entre el $11 \%$ y $25 \%$ del área total de muros, incluso existe un $26 \%$ de edificios donde una dirección cuenta con tan solo un $7 \%$ a $\mathbf{1 0} \%$ del área total de muros.
Furthermore, the model considers process for qualifying the vulnerability rate as a mechanism to qualify the structural state.

- The vulnerability functions were compared to those of project WP4 RISK EU, finding some similar results of those obtained by the two other methods.

- The system of concrete walls represents a $41.83 \%$ of the buildings in Bucaramanga. This means that is one of the most used since the implementation of code NSR-98. According to the results obtained in the masonry, (Maldonado et al., 2008) the level of damage for the possible seismic scenerios in the city are reduced.

- During the process of modelling the buildings a deficiency of walls parallel to the front was observed, as typically in these constructions. This was not evident during the inspection on site, this is only identifiable during the analysis of plans.

- The visual inspection revealed the problem of a lack of separation in the adjacent buildings; which becomes even more serious due to plates at different levels among them, because this produces strong shear forces that hit the structure during an earthquake.

- The analysis of the results of the sample parameters shows that most of the buildings qualify between $A$ and $B$, which belong to the degrees that represent the lesser degree of vulnerability, that is why finally the buildings are within the range from few to somehow vulnerable. Nevertheless, those parameters that produced a negative influence are represented in the deficiency at the third parameter (Conventional Strength), this is because is placed in a single direction, and then it does not give the structure equal stiffness in both directions. This aspect is evident with the percentage of walls in the weaker direction in comparison with the total wall area, thus a $42 \%$ of buildings with walls in a single direction is between $11 \%$ and $25 \%$ of the total area of walls, even there is a $26 \%$ of buildings where a single direction is only between $7 \%$ and $10 \%$ of the total area of walls. 
Tan solo en el $18 \%$ de las edificaciones el porcentaje de área de una dirección con respecto a la otra está entre el $35 \%$ y $50 \%$ y un $13 \%$ está entre el $26 \%$ y $35 \%$.

- A su vez, otros parámetros que influyeron negativamente, pero en mejor grado de importancia, fueron los relacionados con las irregularidades en planta y en altura. Pues con respecto a la planta tan solo el $\mathbf{3 0} \%$ de las edificaciones se pueden considerar que cuentan con plantas regulares y con respecto a la irregularidad en altura el $30 \%$ de la muestra total presenta problemas por cambio de masa o rigidez entre un nivel y otro.

\section{Agradecimientos}

Este trabajo forma parte de los resultados del proyecto de investigación titulado Zonificación del Riesgo Sísmico en Centros Urbanos Utilizando Funciones Calculadas. Caso de estudio: Meseta de Bucaramanga, el cual fue financiado por la Universidad Industrial de Santander, UIS, y por el Instituto Colombiano para el Desarrollo de la Ciencia y la Tecnología Francisco José de Caldas, COLCIENCIAS.
Only in the $18 \%$ of buildings the percentage of area from one direction to the other is within $35 \%$ and $50 \%$; and a $13 \%$ is between $26 \%$ and $35 \%$.

- The parameters that influenced negatively, by its side but with less degree of significance, were those related to irregular plants and height. According to plant, only the $30 \%$ of buildings is considered with regular plants; the $30 \%$ of the total simple shows problems of irregularities at height due to changes or stiffness in mass between on level or other.

\section{Acknowledgements}

This paper is part of the results of the project called Zonification for Seismic Risks in Urban Areas using Calculated Functions. Case of study: Plateau of Bucaramanga, which was financed by the Universidad Industrial de Santander, UIS, and by Instituto Colombiano para el Desarrollo de la Ciencia y la Tecnología Francisco José de Caldas, COLCIENCIAS.

\section{Referencias / References}

Asociación Colombiana de Ingeniería Sísmica (1998), Normas Colombianas de Diseño y Construcción Sismo Resistente, NSR-98, Bogotá, Colombia.

Asociación Colombiana de Ingeniería Sísmica (1984), Código Colombiano de Construcción Sismo Resistente, CCCSR-84, Bogotá, Colombia ATC (1985), Applied Technology Council. Earthquake damage evaluation data for California, ATC-13, Redwood City, California, USA. ATC 40 (1996), Applied Technology Council Seismic. Evaluation and Retrofit of Concrete Buildings, Vol.1, California. Bandemer H., Gottwald S. (1996), Fuzzy sets, fuzzy logic, fuzzy methods with applications, Jhon Wiley and Sons, New York. Benedetti D., Petrini V. (1984), Sulla vulnerabilitá sísmica di edifici in muratura: Proposte di un método di valutazione, L'industria delle Costruzioni, Vol. 149, pp. 66-78, Roma, Italia.

Caicedo C., Barbat A., Canas J. A. y Aguiar R. (1994), Vulnerabilidad sísmica de edificios, Monografías de Ingeniería Sísmica, Vol. IS-6 España: CIMNE, Editor A. H. Barbat.

Gent K., Astroza M., Giuliano G. (2005), Calibración del índice de vulnerabilidad del GNDT a las edificaciones chilenas: Estructuras de albañilería confinada, Congreso Chileno de Sismología e Ingeniería Antisísmica, IX Jornadas, Concepción, Chile. INGEOMINAS - CDMB (2002), Microzonificación Sismogeotécnica Indicativa del Área Metropolitana de Bucaramanga. Bucaramanga. Jiménez J. (2002), Vulnerabilidad sísmica de las edificaciones de la ciudad de Cuenca mediante técnicas de simulación, Tesis para obtener el grado de Maestría, Escuela Politécnica Nacional, Quito, Ecuador.

Maldonado E., Chio G. (2008), Vulnerabilidad sísmica de centros urbanos, Ediciones Universidad Industrial de Santander, Bucaramanga. Maldonado E. Chio, G. Gómez, I. D. (2008a), Funciones de vulnerabilidad y matrices de probabilidad de daño sísmico para edificaciones de mampostería utilizando técnicas de simulación, DYNA, Año 75, No. 155, pp. 63-76,

Maldonado E., Chio G., Gómez I. D. (2008b), Simulación de funciones de vulnerabilidad y matrices de probabilidad de daño sísmico para edificaciones de hormigón armado en sistema pórtico, Ingeniería e Investigación, Vol. 28, No. 3, pp. 28-40.

Maldonado E., Chio G. (2009), Estimación de las funciones de vulnerabilidad y matrices de probabilidad de daño sísmico para edificaciones en tierra, Ingeniería \& Desarrollo, No. 25, pp. 180-199.

Mena U. (2002), Evaluación del riesgo sísmico en zonas urbanas, Tesis para obtener el título de Doctor, Universidad Politécnica de Cataluña, Barcelona, España.

Milutinovic Z., Trendafiloski G. (2003), WP4 Vulnerability of current buildings. RISK-UE: An advanced approach to earthquake risk scenarios with applications to different European towns. Contrato No. EVK4-CT-2000-00014, 108 pp.

Terano T., Asai K., Sugeno M. (1992), Fuzzy system theory and its aplications, Boston: Academia Press.

Yépez F. (1996), Metodología para la evaluación de la vulnerabilidad y riesgo sísmico de estructuras aplicando técnicas de simulación, Tesis de grado para obtener el título de Doctor, Universidad Politécnica de Cataluña, Barcelona, España,.

Zadeh,L. A. (1965), Fuzzy sets, Information and control, 8. 